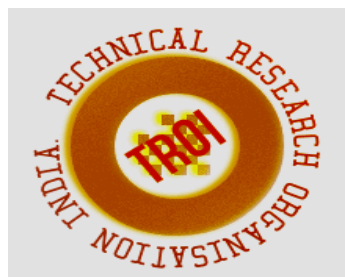

\title{
LEADERSHIP STYLES AND ITS EFFECTIVENESS: A CASE STUDY IN PUBLIC AND PRIVATE SECTOR OF INDIA
}

\author{
Lalbihari Barik \\ Department of Information Systems, Faculty of Computing \& Information Technology in Rabigh, \\ King Abdulaziz University, Kingdom of Saudi Arabia. \\ Email: lalbihari@gmail.com
}

\section{Abstract}

Objectives of this research are to see the significant difference if any between executives and Supervisors belonging to a public \& private organization to the need for fulfillment. It is also to see the significant difference if any between executives supervisors belonging to a public \& private organization concerning the leadership styles \& their effectiveness. There is also to see the significant difference in leadership styles \& their effectiveness if any between a satisfied \& dissatisfied group of respondents (executives \& supervisors) with lower order needs in public \& private organizations. The study was conducted independently in two large organizations of India. One is a public organization (Oil and Natural Gas Corporation, Surat) and the other one is a private organization (Essar Oil, Surat). The samples were collected on executives and supervisors of these organizations. The executives hold a distinct designation of managers/executives. ONGC, Surat was selected as a public organization and Essar Oil, Surat was selected as a private organization. A sample of 980 (public 430 and private 550) executives and the supervisor was given the porter need satisfaction questionnaire to measure the need fulfillment/dissatisfaction. The conclusion of the study is the executives of the public, and private organizations are not significantly different in case of the lower order needs and the result on higher order needs manifests that executives of the organizations are significantly different with each other. The supervisors of the public and privet organization are significantly different from each other. In need Hierarchy Level, i.e., lower and higher order needs. The respondents (executives and supervisors) of the public organization have preferred high relationship-low task leadership behavior as their dominant behavior.

On the other hand, the respondents (executives and supervisors) of privet organization have preferred high task-high relationship behavior as their dominant behavior. The effectiveness variables imply that executives of public organist ions are more effective in comparison to executives of privet organizations, while supervisors of both organizations are equally effective. Because it is noted that the supervisor of both organizations are not significantly different from each other. This type of analysis of leader's (executives and supervisors) needs may be important for placing and promoting them. The need factor influences the productivity of any organist ion because it is supposed that the success of an organization depends upon the need and activities of the employees. This study is very important not only from the academic angle but also in practice terms and would be helpful to identify the difference between the two distinct managerial levels in an organization and the distinction between the two organizations.

Index Terms: Leadership Styles, Leadership Style's Effectiveness.

\section{INTRODUCTION}

In the present time, many organizations suffer from the unmotivated workforce, and it does not bubble from the bottom but percolates from the top level of employees. Thus efforts have to be 
made to motivate the employees from the top to develop enthusiasm and commitment among staff members. The success of an organization depends upon the level of motivation of its members and appropriates of the leadership pattern in a particular situation. An extremely motivated group of employees can help the organization sustain even in the worst type of environmental conditions. On the other hand, the success of an organization might be jeopardized, if the employees of the organization are not motivated towards the workforce.

Both leadership and motivation are very popular concepts, and a tremendous amount of work has been done by several researchers in different areas like industry, business, etc. in different ways, but it was realized that further studies are needed in the field of leadership and motivation, especially in public and private organizations. Every economic or political system or business enterprise or commonwealth organization derives its continued existence from the successful guidance of human beings. Thus the leadership role relates to human aspects of administration. The understanding of human factors, the process of influence and communication, group behavior, intergroup behavior organizational dynamics, and several other things are utmost significance for a manager to be a successful one.

\section{Concept of leadership}

The study of leadership has been an important and central part of the literature on management and organization behavior for several decades. Indeed, no other role in organizations has received more interest than that of the leader (Schwandt \& Marquardt, 2000). The concept of leadership has been studied since ages dating back to the times of Plato, Caesar (Bass, 1981). Over the years, researchers have generated a surplus of work and data that adds value in the field of leadership research. Although leadership is just an expression that is often used in conversation and is frequently described by various adjectives such as good leadership, influential leadership, effective leadership, poor leadership, and bad leadership. Most scholars have concluded that the concept of leadership does not attribute to one specific definition. Although a lack of harmony continues to exist about an exact meaning for guidance, most of the researchers agree that leadership is an influence relationship between the leaders and the follower who have their shared purposes and the leader achieves goals through continuous inspiration and motivation of their followers. It is very important to have a better understanding of the historical evolvement of the concept of a leader and the leadership. For this study, a discussion of these concepts will be provided as they originate from traditional leadership theories of the mid-1900s to the more modern theories of leadership.

\section{Concept of Motivation}

Investigators have attempted to define motivate according to their research purpose and use one or a word like desires, wants, wishes, aims, goals, drives, motives, and incentives. "Motive is an inner that directs or channels behavior toward the goal" (Berel and Steiner, 1964). The mechanism of motivation can be regarded as a movement towards a balance. This movement towards equilibrium is a homeostatic mechanism. Need is a start point of this mechanism and its [Need] is a deficiency something within the living system. When a deficiency caused in this system, it indicates a chain of events. So thing takes place some activity happens but it, not a random activity. The individual who experiences a does not engage in random behavior or haphazard activity; rather he engages himself in activity which is direct toward a goal. As soon as individual reaches the goal, I need satisfied and the mechanism of motivation and therefore motivation is initiated with the need and ended with need satisfaction with goal-directed behavior being the basic dynamic phase of the process.

\section{REVIEW OF LITERATURE}

Reichmann (1991), examined the characteristics of team leaders in higher education. Team leaders exhibited certain characteristics including conceptual leadership and attributes such as honesty, integrity and a sense of fairness. He conducted a study on team leader effectiveness, high-performance teams in higher education and mainly observed the characteristics of team leaders. Northouse (2001), leadership is described as the selection of bases of influence. The transformational approach views leadership as a shared process. 
The outcome of this process is the ability to transform oneself, others, and the organization to new, unimagined heights of motivation and performance.

Alpana Priyabhashini, Venkat R. Krishnan (2005), studied the relationship between transformational leadership, leader's expectation from a follower (Pygmalion effect) and follower's readiness for promotion using a sample of 101 managers from two organizations in India. Respondents answered questions on their readiness for promotions and on their superior's transformational leadership and expectations. The readiness for promotion was captured through two dimensions. The first one related to motivation of the subordinate to perform and to rise. The second dimension was measured on the confidence of the subordinate. The results showed that the leader's expectation was significantly positively correlated to the follower's readiness for promotion. Each of the five factors of transformational leadership was significantly positively correlated to the leader's expectation. Readiness for promotion is positively related to only three factors of transformational leadership-idealized influence, inspirational motivation, and intellectual stimulation and is not related to the fourth factor-individualized consideration. Results also showed that leader's expectation mediates.

David.M.Harold, Donald.B.Fedor (2008), in this study, investigated the effect of transformational and change leadership on employee's commitment to a change. The effects of transformational leadership on the outcomes of specific change initiatives are not well understood. Omar Bin Sayeed, Meera Shankar(2009), in their study attempted to examine multivariate relationships between emotional intelligence and transformational leadership. The canonical correlation between emotional intelligence and transformational leadership dimensions revealed significant relationships, which confirmed emotional intelligence as an important element of managerial temperament. Meera Shankar(2009), in their study, attempted to examine multivariate relationships between emotional intelligence and transformational leadership. The canonical correlation between emotional intelligence and transformational leadership dimensions revealed significant relationships, which confirmed emotional intelligence as an important element of managerial temperament.

Vimal Babu (2011), studies have emphasized that expatriates leadership styles play a pivotal role. It has been considered a prime criterion to be successful and effective in the host country. The study has examined 25 Japnese and 23 American expats in India focusing on their leadership styles. In order to determine the leadership styles of these managers from altogether different countries, the study has investigated ten leadership components. Results were analyzed to identify the differences and similarities between the leadership styles. Statistical tests revealed that there were significant differences in four leadership components out of ten and the remaining six leadership components had non-significant differences. Results showed that American managers had good communication skills. Japanese managers often motivated their subordinates to work harder by stating clearly what the desired performance is and what is not. American managers had more knowledge and skills to transfer and train their subordinates. The study also sheds light on the implications for expatriates with regard to leadership effectiveness.

Rezvan Mirsafaei Rizi, Aida Azadi, Maryam Eslami Farsani, Shahram Aroufzad(2013), the relationship between leadership styles and job satisfaction among physical education organization employees in Isfahan. Results showed that the positive correlation between overall leadership styles and job satisfaction was significant at the level of $\mathrm{P}<0.05$. Also, the correlations between leadership styles sub-scales such as transactional leadership, transformational leadership, and passive/avoidant leadership and job satisfaction were significant at the level of $\mathrm{P}<0.05$. Based on these results, among determinants of job satisfaction, leadership is viewed as an important predictor and plays a central role.

In present investigations, the attempt has been made to know the need fulfillment (lower order need security and social. Higher-order need self-actualization), leadership styles (HT-LR, HT-HR, HR-LT, and LR-LT) and leadership effectiveness in public and private organizations 
respondents (executives and supervisors). It is assumed that motivation / needs play a very prominent role in the personality \& behaviors of individual \& it is supported by Richards \& green law (1972) because they have mentioned in their studies that they need \& values of leader may have considerable influence on the leadership behaviors which they will choose. In this contest, the attempt has been made to study the influence of need satisfaction \& dissatisfaction on the leadership styles \& their effectiveness \& to measure the relationship of lower $\&$ higher order need satisfaction with style in public \& private organizations.

\section{Objectives}

The objective of the present study is the following;

To see the significant difference if any between executives and Supervisors belonging to public \& private organization with respect to the need for fulfillment.

To see the significant difference if any between executives supervisors belonging to a public \& private organization with respect to the leadership styles \& their effectiveness.

To see the significant difference in leadership styles \& their effectiveness if any between a satisfied \& dissatisfied group of respondents (executives \& supervisors) with lower order needs in public \& private organizations.

\section{Hypotheses}

Keeping in view of the above objectives, the following hypotheses have been tested in this study:

H1. Public and private organization executives and supervisors would be significantly different from their need of fulfillment.

H2. There would be a significant difference between public and private organization executives and supervisors in terms of styles of leadership and their effectiveness.

H3. Leadership styles and their effectiveness would be significantly different between a satisfied and dissatisfied group of executives and supervisors with lower order needs in public organizations.

H4. Leadership styles and their effectiveness would be significantly different between a satisfied and dissatisfied group of supervisors with lower needs in public organizations.

H5. Leadership styles and their effectiveness would be significantly different between a satisfied and dissatisfied group of executives with lower needs in private organizations.

H6. Leadership styles and their effectiveness would be significantly different between a satisfied and dissatisfied group of supervisors with lower needs in private organizations.

In this study need fulfillment, public and private organizations, executives and supervisors are independent variables. However, Leadership styles and leadership effectiveness are dependent variables.

\section{RESEARCH METHODOLOGY}

An organization is a structured process in which persons interact for objectives. In other ways, it may be defined as a human group deliberately and consciously created for the attainment of certain goals with rational coordination of closely relevant activities. For the research purpose, one public sector (ONGC, Surat) and one private sector (Essar Oil, Surat) organization were selected, and both are the reputed and large scale organization in India. A pilot study was conducted in both of them, and the data for the final study was collected from both the organizations because they were judged as the most appropriate due to the availability of a large number of executives and supervisors as a leader and both are the engineering and manufacturing organizations.

\section{Sample}

The study was conducted independently in two large organizations of India. One is a public organization (Oil and Natural Gas Corporation, Surat.) and the other one is a private organization (Essar Oil, Surat). The samples were collected on executives and supervisors of these organizations. The executives hold a distinct designation of managers/executives. The supervisors are categorized in lower level management and also known as foreman. The categorization of employees was based on the organizational framework/structure adopted by ONGC and Essar Oil for the above categorization.

\section{Instruments used}

Forter's need satisfaction and leader effectiveness adaptability description questionnaires were selected and administered to measure the motives / needs, leadership styles 
administered to measure the motives / needs, leadership styles and leadership effectiveness of the executives and supervisors. Both (PNS and LEAD) are structured questionnaires. It is thought that there is no need to measure the reliability and validity of both LEAD and PNS questionnaires in Indian settings because the various investigators i.e. Rastogi (1978) Gupta (1978), Ganesan (1978), Khandelwal (1986) need, Pathak and Singh (1981), Srinivasan (1990), Gupta (1978), Kool and Sazena (1989) leadership styles and effectiveness, have already used both (LEAD AND PNS in Indian setting with different perspectives.

\section{DATA ANALYSIS}

H1. (A) Public and private organization

Table 1 (A) difference if any between executives belonging to a public \& private organization with respect to the need for fulfillment

\begin{tabular}{|c|c|c|c|c|c|c|}
\hline \multirow[t]{3}{*}{ Executives } & \multicolumn{6}{|c|}{ Need Areas } \\
\hline & \multicolumn{3}{|c|}{ Lower Order Need } & \multicolumn{3}{|c|}{ Higher Order Need } \\
\hline & Mean & S.D. & ' $\mathrm{t}$ ' & Mean & s.d. & ' $\mathrm{t}$ ' \\
\hline $\begin{array}{l}\text { Public organization } \\
(\mathrm{N}=180)\end{array}$ & 54.85 & 6.69 & $1.44^{* *}$ & 69.72 & 7.73 & $8.16^{* *}$ \\
\hline $\begin{array}{l}\text { Private organizations } \\
(\mathrm{N}=200)\end{array}$ & 55.77 & 5.72 & & 59.25 & 6.88 & \\
\hline
\end{tabular}

$* * \mathrm{P}<0.01$

Note: The higher mean score signifies dissatisfaction lower mean score signifies satisfaction with needs.

H1 (B) public and private organization supervisors would be significantly different in their need fulfillment.

Table 1 (B) presents the need fulfillment of the supervisors of both public and private organizations at the two need hierarchical levels and private organizations at the two needs hierarchical levels, i.e., lower order need and higher order need. The mean score of lower order needs refers that supervisors of the public organization are more satisfied in comparison to

Table 1 (B) Lower and higher order need fulfillment of supervisors in public and private organization.

\begin{tabular}{|c|c|c|c|c|c|c|}
\hline \multirow[t]{3}{*}{ Executives } & \multicolumn{6}{|c|}{ Need Areas } \\
\hline & \multicolumn{3}{|c|}{ Lower Order Need } & \multicolumn{3}{|c|}{ Higher Order Need } \\
\hline & Mean & S.D. & ' $\mathrm{t}$ ' & Mean & s.d. & 't' \\
\hline $\begin{array}{l}\text { Public organization } \\
(\mathrm{N}=250)\end{array}$ & 56.03 & 5.58 & $8.16^{* *}$ & 68.05 & 6.74 & $18.08 * *$ \\
\hline $\begin{array}{l}\text { Private organizations } \\
(\mathrm{N}=350)\end{array}$ & 60.04 & 6.54 & & 58.65 & 5.74 & \\
\hline
\end{tabular}

$* * \mathrm{p}<0.01$ 
Table 1 (A) and (B) reported that respondents of public organization and executives of private organization perceive increasing order of dissatisfaction from lower to higher order needs. These results represent the trend of Maslow's need hierarchy theory because Maslow predicted that needs are arranged in a hierarchy of prepotency such that lower order needs are inherently more important than the higher order need. This implies that before any of the higher level need, individuals lower order need must satisfied.

Table 1 (A) and (B) display that respondents of the public organization are more satisfied with their lower order need than the respondents of the private organization. But it is noted that executives are insignificantly different from each other. On the other hand, supervisors are significantly different from each other. This finding also emphasis that respondents (Executives and supervisors) are more dissatisfied with their higher order need in comparison to the respondents of the private organization. Therefore, $t$ value (Table $1 \mathrm{~A}: \mathrm{t}=8$, 98, $\mathrm{P}<0.01$ ) and table $-1 \mathrm{~B}: \mathrm{t}=18.43, \mathrm{P}<0.01$ ) indicates the significant differences in respondents of both organizations on higher order need. On the basis of this finding. It can be said that the environment, organizational structure, and job hierarchical level influence the satisfaction/ dissatisfaction of the leaders in both organizations.

This concept is supported by Rosen and Weaver (1960), Porter (1961), Mahewswari (1960) and Sharma (1990), Sharma (1990) noted that the satisfaction of an individual's need depends to a great extent on the environment. Thus, the organizational climate gains pivotal importance. Maheswari (1960) conducted a study on perceived need satisfaction and importance among supervisory and managerial personnel in the engineering industry and noted that occupational level greatly influences the perception of need deficiency and importance. Also found that three of the need categories social self-esteem and autonym produced statistically significant means difference between supervisors and managers. She also reported that whereas supervisors have the lesser opportunity of independent thought either managers have a greater opportunity of personal growth, independent thought, action and participation in the determination of method and procedure.

Salient reason for the significant difference in both organizations may be that respondents of the public organization are not more intrinsically motivated, they are highly motivated by their extrinsic rewards such as salary, overtime, cost of living, adjustment, profit sharing benefits, incentive plans, permanent position and job security in the organization. Lower order needs are related to corporate profitability and survival rather than organizational self-actualization.

Zenisek (1979) speculated the organizational security and survival all are satisfied in the context of classical economic norms, by means of the organizational response mechanism. Another conceivable explanation is that employee of the public organization are better informed and more knowledgeable of their indirect economic benefits. On the other hand, respondents of private organizations are intrinsically motivated with their challenging job, personal growth and accomplishment. Blumenthal and Rainey have reported that executives of public organizations have higher formalization and less autonomy in hiring, firing or rewarding than do executives of the private organization and also noted that these limits could affect on the levels of satisfaction.

\section{H2. (A) There would be a significant} difference between public and private organization executives in terms of styles of leadership and their effectiveness.

Table 2(A) reveals the self-perception of the executives of the public and private organization about the leadership styles and their effectiveness. Mean scores indicate that executives of the public organization have achieved the highest score on high relationship low task leadership behavior. So it becomes clear that executives of the public organization have adopted high relationship low task leadership behavior as their basic secondary style low relationship low task releasing leadership behavior in statistically insignificant and shows some consistency in public and private organization executives on this leadership behavior. 
Table 2 (A) Leadership styles and their effectiveness among public and private organization executive.

\begin{tabular}{|c|c|c|c|c|c|c|}
\hline \multirow[t]{2}{*}{ Executives } & \multirow{2}{*}{$\begin{array}{l}\text { Mean } \\
\text { \& S.D }\end{array}$} & \multicolumn{4}{|c|}{ Leadership Styles } & \multirow{2}{*}{$\begin{array}{l}\begin{array}{l}\text { Leadership } \\
\text { effectiveness }\end{array} \\
\text { Need }\end{array}$} \\
\hline & & HT LR & HT HR & HR-LT & LR-LT & \\
\hline $\begin{array}{l}\text { Public } \\
\text { organization } \\
(\mathrm{N}=180)\end{array}$ & $\begin{array}{l}\text { Mean } \\
\text { S.D. }\end{array}$ & $\begin{array}{l}1.74 \\
1.29\end{array}$ & $\begin{array}{l}3.90 \\
2.44\end{array}$ & $\begin{array}{l}4.20 \\
1.84\end{array}$ & $\begin{array}{l}2.22 \\
2.68\end{array}$ & $\begin{array}{l}0.04 \\
5.29\end{array}$ \\
\hline $\begin{array}{l}\text { Private } \\
\text { organiatons }\end{array}$ & $\begin{array}{l}\text { Mean } \\
\text { s.d. }\end{array}$ & $\begin{array}{l}2.44 \\
1.57 \\
\end{array}$ & $\begin{array}{l}4.33 \\
2.11 \\
\end{array}$ & $\begin{array}{l}3.58 \\
1.65 \\
\end{array}$ & $\begin{array}{l}1.64 \\
1.84 \\
\end{array}$ & $\begin{array}{l}3.52 \\
6.61 \\
\end{array}$ \\
\hline $\begin{array}{l}\text { Public vs } \\
\text { Private } \\
\text { supervisors }\end{array}$ & $\begin{array}{l}\text { 't' } \\
\text { Value }\end{array}$ & $5.38 * *$ & 1.95 & $3.65 *$ & 2.42 & $4.31^{* *}$ \\
\hline
\end{tabular}

$* \mathrm{P}<0.05$

$* * \mathrm{p}<0.01$

HT-LR = High Task - Low Relationship

HT-HR= High Task - High Relationship

HR LT $=$ High Relationship Low Task

LR-LT = Low relationship - Low Task

And high task low relationship ( $\mathrm{M}=1,74$, S.D=1.29) Leadership behavior is preferred by the executives in the third and last position.

In contrast, executives of private organizations have achieved the highest score on high task high relationship $(\mathrm{M}=4,33, \mathrm{~S} . \mathrm{D}=2.11)$ leadership behavior. It shows that the executives of the private organizations have adopted high task high relationship leadership behavior as their dominant behavior and high relationship behavior as their dominant behavior and high relationship low task (M=3.58, S.D.=1.65) leadership behavior as a supportive behavior. Low relationship, low task $(\mathrm{M}=1,64$. S.D. $=1$, 84) leadership behavior is least preferred by the executives of the private organization.

Mean score of leadership effectiveness depicts that executives of the public organization have achieved the greatest score (M=6.04, S.D.=5.29) rather than executives $(M=3.52$, S.D. $=6.61)$ of a private organization. Therefore a significant difference is obtained between executives of public and private organizations in leadership effectiveness.

H2 (B) There would be a significant difference between public and private organization supervisors in terms of styles of leadership and their effectiveness.

Table 2(A) also reveals that executives of both the organizations are significant to the extent of high task low relationship ( $\mathrm{t}=5.38, \mathrm{p}<0.01)$, high relationship low task $(\mathrm{t}=3.65$., $\mathrm{p}<0.01)$ and low relationship low task leadership behavior. While high task high that supervisors of public organizations have achieved the highest score on high relationship low task $(M=3.98, S . D .=1.88)$ leadership behavior. However, it is clear that high relationship low task leadership behavior is the dominating behavior of the supervisors in public organization. This leadership behavior (HT-LT) of the supervisors are supported by the high task - high relationship $(\mathrm{M}=3.67$, S. $D=2.21$ ) leadership behavior.

On the other hand, supervisors perceive the high task high relationship (M-3.63,S.D=1.91) leadership behavior as a favorite behavior / style in private organization. Favorite behavior (HT-HR) is supported by supervisors with high relationship low task $(\mathrm{M}=3.47, \mathrm{~S} . \mathrm{D}=1.77)$ leadership behavior.

Leadership effectiveness variable reveals that supervisors of the public organization have obtained 4.93 (S.D. $=5.55$ ) SCORE AND SUPERVISORS of the private organization have obtained 4.10 (S.D. = 6.01) score. High task low relationship $(\mathrm{t}=5,54, \mathrm{p}<0.01)$ and high relationship low task $(\mathrm{t}=3,92, \mathrm{p}<0.01)$ leadership behavior display the significant difference. High task high relationship and low task low relationship leadership behavior show insignificant difference among the public and private organization superiors. In terms of leadership effectiveness, public and private organization supervisors are equally effective 
and mean difference $(\mathrm{MD}=0.83)$ is statistically insignificant

Table : 2 (B) Leadership styles and their effectiveness among public and private organization supervisors.

\begin{tabular}{|l|l|l|l|l|l|l|}
\hline Supervisors & $\begin{array}{l}\text { Mean } \\
\text { \& S.D. }\end{array}$ & \multicolumn{4}{|l|}{ Leadership Styles } & $\begin{array}{l}\text { Leadership } \\
\text { effectiveness }\end{array}$ \\
\cline { 2 - 8 } & & HT LR & HT HR & HR-LT & LR-LT & Need \\
\hline $\begin{array}{l}\text { Public } \\
\text { organization } \\
(\mathrm{N}=250)\end{array}$ & Mean & 2.00 & 3.67 & 3.98 & 2.32 & 4.93 \\
S.D. & 1.47 & 2.21 & 1.88 & 2.26 & 5.55 \\
\hline $\begin{array}{l}\text { Private } \\
\text { organiatons } \\
(\mathrm{N}=350)\end{array}$ & Mean & 2.72 & 3.63 & 3.47 & 2.16 & 4.10 \\
\hline $\begin{array}{l}\text { Public vs } \\
\begin{array}{l}\text { Private } \\
\text { supervisors }\end{array}\end{array}$ & 1.76 & 1.91 & 1.77 & 1.81 & 6.01 \\
$* *$ P $<0.01$ & 't' & $5.54^{* *}$ & $0.23^{* *}$ & 3.92 & 0.94 & 1.76 \\
\hline
\end{tabular}

The finding reveals that respondents of the public organization have adopted high relationship low task leadership behavior as their dominant behavior. This dominant (HR-LT) leadership behavior is also knowns participating in leadership behavior, and it is defined as a participating leadership behavior and it is defined as a "process on which two or more group influence each other in making plans or decisions, and this behavior focuses on the degree to which subordinates can share the power of their seniors and also influence their decisions (Maheswari, 1980). High relationship low task leadership behavior of the leader refers that subordinates have moderate to high maturity in the public organization (maturity level of the subordinate is determined by the situational leadership theory of Hersey and Blanchard, 1983). At this maturity level, subordinates learn the job thoroughly and begin to take the initiative on job-related matters. Therefore the leaders assume that subordinates are capable of sharing the decision-making process. In this process, a leader reflects his own views and tries to understand the views of his subordinate then take the decision. Situational leadership theory also emphasizes that high leadership - low task leadership behavior of the leader has the highest probability of being effective with subordinates at the moderate to high maturity level. However, it is clear that executives and supervisors use participating behavior in public organization. This participating leadership behavior has a similar concept as democratic leadership behavior (white and Lipitt, 1958). These leadership behaviors (participating / democratic) emphasize on the relationship between leader and subordinate by opening up channels of communication providing socio-emotional support psychological strokes and facilitating behavior.

An examination of table 2(a) and 2(b) shows that executives and supervisors have adopted a similar pattern of leadership behavior (HR-LT, HR-HR, LR-LT, and HT-DR) in the public organization. The patter of leadership behavior indicates that job hierarchical level does not affect the leadership behavior. Hill (1973) has also mentioned in his study that organizational level does not affect the leadership behavior. Consequently, both the respondents (executives and supervisors) play an equal and significant role in decision making and responsibility, etc. most of the respondents have preferred participating leadership behavior.

Contradiction to the above finding a similar type of finding is reported by Sinha (1973), that beaurocratic system is prevalent (dominant) in public organization. On the basis of the worker's expectations, Desai (1969) noted that worker preferred good relations with supervisors. High task high relationship and low relationship low task leadership behavior are used by the executives and supervisors as a secondary leadership behavior. The least score of high task low relationship (leader provide specific instructions to his subordinate and closely supervise performance) leadership behavior exhibit that most of the respondents of public organization do not believe in this leadership 
behavior (HT-LR). The high task low relationship leadership behavior is known as autocratic leadership behavior, and this behavior emphasizes on task-related matters. In a cross-cultural study conducted by Mead and Whittaker (1967), they reported that the authoritarian tendency exhibited by Americans was more than in Indians and Rhodesians.

On the other hand, high task-high relationship leader-ship behavior is dominating in the respondents (executives and supervisors) of the private organization. This leadership behavior (HT-HR) reflects that they have not only limited their attention to the task to be performed but provide similar attention to the relationship with the people (subordinate and colleagues). Combination of the task and relationship behavior is the conducive to the people and the organization. Argyris (1970) conducted an experiment and found that broadening individual responsibility is beneficial to both the workers and the company. Respondents of private organization perceive that their subordinates have low to moderate maturity level. At this maturity level subordinates are willing to take responsibility and feel confident themselves, so the leader recognizes the employee's potential and encourages it through the strong task and emotional support. Most of the decision is still provided by the leaders in private organizations.

\begin{tabular}{|c|c|c|c|c|c|c|}
\hline \multirow{2}{*}{$\begin{array}{lr}\text { Satisfied } & \text { and } \\
\text { dissatisfied } & \\
\text { group } & \text { of } \\
\text { Supervisors } & \text { with } \\
\text { lower } & \text { order } \\
\text { needs } & \end{array}$} & \multirow{2}{*}{$\begin{array}{l}\text { Mean \& } \\
\text { S.D }\end{array}$} & \multicolumn{4}{|c|}{ Leadership Styles } & \multirow{2}{*}{$\begin{array}{l}\begin{array}{l}\text { Leadership } \\
\text { effectiveness }\end{array} \\
\text { Need }\end{array}$} \\
\hline & & HT LR & HT HR & HR-LT & LR-LT & \\
\hline $\begin{array}{l}\text { Satisfied } \\
\text { supervisors } \\
(\mathrm{N}=65)\end{array}$ & $\begin{array}{l}\text { Mean } \\
\text { S.D. }\end{array}$ & $\begin{array}{l}1.57 \\
1.08\end{array}$ & $\begin{array}{l}4.46 \\
2.29\end{array}$ & $\begin{array}{l}4.98 \\
1.79\end{array}$ & $\begin{array}{l}0.96 \\
1.26\end{array}$ & $\begin{array}{l}7.18 \\
5.08\end{array}$ \\
\hline $\begin{array}{l}\text { Dissatisfied } \\
\text { supervisors } \\
(\mathrm{N}=52)\end{array}$ & $\begin{array}{l}\text { Mean } \\
\text { s.d. }\end{array}$ & $\begin{array}{l}1.58 \\
1.35\end{array}$ & $\begin{array}{l}2.20 \\
1.48\end{array}$ & $\begin{array}{l}3.79 \\
1.72\end{array}$ & $\begin{array}{l}4.42 \\
2.62\end{array}$ & $\begin{array}{l}5.14 \\
5.62\end{array}$ \\
\hline $\begin{array}{l}\text { SATISFIED VS } \\
\text { Dissatisfied } \\
\text { supervisors }\end{array}$ & $\begin{array}{l}\text { 't' } \\
\text { Value }\end{array}$ & 0.04 & $6.28 * *$ & $3.40 * *$ & $8.44^{*}$ & 1.90 \\
\hline
\end{tabular}

It is interesting to find that, (table $2 \mathrm{~A}$ and 2B)respondents of the private organization have also adopted a similar pattern of leadership behavior, i.e., HT.HR, HR-LR, and LR-LT, while respondents of the public organization have adopted, i.e., HR-LT, HT-HR, LR-LT, and HT-LR leadership behavior (Fig.1 and 2). It is identified that most of the leaders having a combination of task and relationship behavior in their leadership style exclusively having either task or relationship behavior and high relationship-low task, high task-low relationship leadership behavior are supporting leadership behavior. This finding is supported by Gupta (1978) and Pratap and Srivastava (1985). Pratap and Srivastava noted that high task-high relationship leadership behavior as a dominating behavior among the executives of the private organization and also noted that result on HR-LT, HT-LR reveals that Indian executives do think on the lines of 'Concern for the people,' but many of them still like to be benevolent autocrats rather than participating managers. The least score on the low relationship -low task leadership behavior exhibit that respondents (executives and supervisors) of the private organization have not believed in the delegation of responsibility, because they assume that their subordinates are not only incapable for taking responsibility and cannot work without guidance or supervision. This consequence is supported by Pynekar and Savur (1969).

It has been seen from the table 2A and 2B that respondents of the public organization have preferred high relation (1986) reveal that leaders prefer their leadership behavior in accordance with the needs of specific situations. So it is clear that executives and supervisors of the public organization have more diagnostic ability to adjust their range of leadership behavior to the different situations appropriately rather than respondents (executives and supervisors) of the 
private organization.

H3. Leadership styles and their effectiveness would be significantly different between the satisfied and dissatisfied group of executives with lower order needs in public organizations.

Table 3 exhibits the leadership style of a high satisfied and less satisfied group of executives with lower order needs in public organization. For the purpose of the study, two groups were selected, i.e., satisfied and dissatisfied with the help of Q1 (satisfied) and Q3 (dissatisfied) statistical technique. Out of 180 executives, 54 executives were put into the category of satisfied $(M=47.67$, S.D. $=2.43)$ and 48 executives were put into the category of dissatisfied $(m=63.39$, S.D $=4.80)$ with their lower order needs and rest of the executives $(\mathrm{N}=78)$ are neither highly satisfied not highly dissatisfied with their lower order needs. The feeling of satisfaction/dissatisfaction is developed in the individuals with the experiences, which they have with the job assigned to them. The behavior patterns of the superiors and the subordinates are also influenced by security (organizational factor) and social relation (Personal factor). Personal factors and behavior are influenced by personality traits, and satisfaction/dissatisfaction of the needs may also influence- leadership effectiveness.

Leadership effectiveness score is different between satisfied and dissatisfied groups, but this difference could not reach the statistically significant ( $\mathrm{t} .=1.90, \mathrm{p}>0.05)$ level.

Table : 3 Leadership Styles and their Effectiveness Between Satisfied and Dissatisfied Groups of Executives with Lower Order Needs in Public Organization.

\begin{tabular}{|l|l|l|l|l|l|l|}
\hline \multirow{2}{*}{$\begin{array}{l}\text { Satisfied and dissatisfied group } \\
\text { of Supervisors with lower order } \\
\text { needs }\end{array}$} & $\begin{array}{l}\text { Mean \& } \\
\text { S.D }\end{array}$ & \multicolumn{3}{|l|}{ Leadership Styles } & $\begin{array}{l}\text { Leadership } \\
\text { effectiveness }\end{array}$ \\
\cline { 2 - 8 } & & HT LR & HT HR & HR-LT & LR-LT & Need \\
\hline Satisfied supervisors (N=65) & Mean & 1.57 & 4.46 & 4.98 & 0.96 & 7.18 \\
& S.D. & 1.08 & 2.29 & 1.79 & 1.26 & 5.08 \\
\hline Dissatisfied supervisors (N=52) & Mean & 1.58 & 2.20 & 3.79 & 4.42 & 5.14 \\
& S.d. & 1.35 & 1.48 & 1.72 & 2.62 & 5.62 \\
\hline $\begin{array}{l}\text { SATISFIED VS Dissatisfied } \\
\text { supervisors }\end{array}$ & 't' & 0.04 & $6.28^{* *}$ & $3.40^{* *}$ & $8.44^{*}$ & 1.90 \\
\hline
\end{tabular}
$* * \mathrm{P}<0.01$

Out of the total number $(\mathrm{N}=250)$ of the supervisors, 65 are satisfied $(\mathrm{M}=49.84$, S.D. = 2.22) and 52 are dissatisfied $(\mathrm{M}=64.11, \mathrm{~S} . \mathrm{D} .=4.38)$ with their lower order need in public organization (table-4). Rest of the supervisors $(\mathrm{N}=133)$ are categorized in the average group. The mean scores of the leadership behavior demonstrate that satisfied supervisors have obtained the highest score on high relationship-low task $(\mathrm{M}=5.14$, S.D. $=1.91)$ leadership behavior and dissatisfied.

H4. Leadership styles and their effectiveness would be significantly different between a satisfied and dissatisfied group of supervisors with lower needs in public organizations.

Table : 4 Leadership Styles and their Effectiveness Between satisfied and Dissatisfied Group of supervisors with Lower Order Needs in Public Organization

\begin{tabular}{|c|c|c|c|c|c|c|}
\hline \multirow{2}{*}{$\begin{array}{lr}\text { Satisfied } & \text { and } \\
\text { dissatisfied } & \text { group of } \\
\text { Supervisors with lower } \\
\text { order needs }\end{array}$} & \multirow{2}{*}{$\begin{array}{l}\text { Mean } \\
\text { \& S.D }\end{array}$} & \multicolumn{4}{|c|}{ Leadership Styles } & \multirow{2}{*}{$\begin{array}{l}\begin{array}{l}\text { Leadership } \\
\text { effectiveness }\end{array} \\
\text { Need }\end{array}$} \\
\hline & & $\begin{array}{l}\text { HT } \\
\text { LR }\end{array}$ & $\begin{array}{l}\text { HT } \\
\text { HR }\end{array}$ & HR-LT & LR-LT & \\
\hline $\begin{array}{ll}\begin{array}{l}\text { Satisfied } \\
(\mathrm{N}=65)\end{array} & \text { supervisors }\end{array}$ & $\begin{array}{l}\text { Mean } \\
\text { S.D. }\end{array}$ & $\begin{array}{l}1.89 \\
1.08\end{array}$ & $\begin{array}{l}3.14 \\
2.16\end{array}$ & $\begin{array}{l}5.14 \\
1.91\end{array}$ & $\begin{array}{l}1.83 \\
1.58\end{array}$ & $\begin{array}{l}7.40 \\
4.2\end{array}$ \\
\hline $\begin{array}{l}\text { Dissatisfied supervisors } \\
(\mathrm{N}=52)\end{array}$ & $\begin{array}{l}\text { Mean } \\
\text { s.d. }\end{array}$ & $\begin{array}{l}1.48 \\
1.48\end{array}$ & $\begin{array}{l}2.61 \\
1.90\end{array}$ & $\begin{array}{l}3.48 \\
1.32\end{array}$ & $\begin{array}{l}4.42 \\
2.48\end{array}$ & $\begin{array}{l}1.54 \\
6.53\end{array}$ \\
\hline $\begin{array}{l}\text { SATISFIED VS } \\
\text { Dissatisfied supervisors }\end{array}$ & $\begin{array}{l}\text { 't' } \\
\text { Value }\end{array}$ & 1.71 & 1.43 & $5.53^{* *}$ & $6.47 * *$ & $5.63 * *$ \\
\hline
\end{tabular}


Table 4 illustrates the leadership behavior of satisfied and dissatisfied groups of executives (satisfaction and dissatisfaction with lower order needs)in private organization and the data shows that 56 executives are satisfied $(\mathrm{M}=49.33$, S.D. $=1.77$ )and 50 executives are dissatisfied $(M=63.26, S . D .=3.83)$ with their lower order needs in the private organization. Remaining executives $(\mathrm{N}=94)$ are neither highly satisfied nor highly dissatisfied with their lower order needs. Mean score of leadership behavior indicates that satisfied as well as dissatisfied executives have adopted high task-high relationship (satisfied, $\mathrm{M}=4.11$, S.D. = 1.72; Dissatisfied, $M=4.78$, S.D.=2.55) leadership behavior as a basic style and high relationship-low task (satisfied, $\mathrm{M}=3.16, \mathrm{~S} . \mathrm{D} .=$ 1.54; Dissatisfied, $M=3.62$, S.D. =1.69) as a supporting style. Rest of the leadership behavior, i.e., high task-low relationship and low relationship-low task are used very less by the satisfied and dissatisfied executives.

H5. Leadership styles and their effectiveness would be significantly different between a satisfied and dissatisfied group of executives with lower needs in private organizations.

Table 5 emphasizes that the satisfied and dissatisfied groups of executives are insignificantly different in the following three leadership behavior, i.e., high task-high relationship (t-1.59), high relationship-low task $(\mathrm{t}=1.53)$ and low relationship-low task $(\mathrm{t}=1.21)$, while both the groups of executives are significantly different $(\mathrm{t}=1.53)$ and low relationship-low task $(\mathrm{t}=1.21)$, while both the groups of executives are significantly different $(\mathrm{t}=2.43, \mathrm{p}<0.05)$ on high task-low relationship leadership behavior.
Table 5 also reveals the consequences of leadership effectiveness of the satisfied and dissatisfied executives (satisfaction or dissatisfaction with lower order need). Satisfied executives have obtained 3.32 score (S.D. = 5.38), and dissatisfied executives have obtained 1.80 (S.D. = 7.36) score on leadership effectiveness, and $t$ (1.21) value indicates the insignificant difference between the satisfied and dissatisfied group of executives in relation to the leadership effectiveness in the private organization.

Out of the total number of the supervisors $(\mathrm{N}=350)$ in private organization (table-6), 82 supervisors are satisfied $(\mathrm{M}=51.22, \mathrm{~S} . \mathrm{D} .=2.51)$ and 80 supervisors are dissatisfied $(M=68.63, S . D .=2.74)$ with their lower order needs, while rest of the supervisors are dissatisfied $(\mathrm{N}=188)$ with their lower order needs. Table 6 exhibits the results on leadership behavior of the satisfied or dissatisfied group of supervisors (satisfaction and dissatisfaction) with lower order need).

Satisfied supervisors have secured the highest score on high task high relationship $(\mathrm{M}=5.21, \mathrm{~S} . \mathrm{D} .=1.73)$ and second highest on high relationship low task $(M=2.93, S . D .=1.59)$ leadership behavior. On the other hand, dissatisfied supervisors have achieved the highest score on high relationship low task $(\mathrm{M}=4.57, \mathrm{~S} . \mathrm{D} .=2.02) \quad$ leadership behavior. However, it is clear that those supervisors are satisfied with lower order needs, they have preferred high task high relationship leadership behavior, while those supervisors who are dissatisfied with lower order needs have preferred high relationship low task leadership behavior in their organization.

Table 5 Leadership styles and their effectiveness between a satisfied and dissatisfied group of executives with lower order needs in private organization.

\begin{tabular}{|c|c|c|c|c|c|c|}
\hline \multirow{2}{*}{$\begin{array}{l}\text { Satisfied and dissatisfied group } \\
\text { of Executives with lower order } \\
\text { needs }\end{array}$} & \multirow{2}{*}{$\begin{array}{l}\text { Mean } \\
\text { \& S.D }\end{array}$} & \multicolumn{4}{|c|}{ Leadership Styles } & \multirow{2}{*}{$\begin{array}{l}\begin{array}{l}\text { Leadership } \\
\text { effectivenes }\end{array} \\
\text { Need }\end{array}$} \\
\hline & & HT LR & HT HR & HR-LT & LR-LT & \\
\hline Satisfied Executives $(\mathrm{N}=65)$ & $\begin{array}{l}\text { Mean } \\
\text { S.D. }\end{array}$ & $\begin{array}{l}2.87 \\
1.52\end{array}$ & $\begin{array}{l}4.11 \\
1.72\end{array}$ & $\begin{array}{l}3.16 \\
1.54\end{array}$ & $\begin{array}{l}1.86 \\
1.55\end{array}$ & $\begin{array}{l}3.32 \\
5.38\end{array}$ \\
\hline Dissatisfied Executives $(\mathrm{N}=52)$ & $\begin{array}{l}\text { Mean } \\
\text { s.d. }\end{array}$ & $\begin{array}{l}2.14 \\
1.52 \\
\end{array}$ & $\begin{array}{l}4.78 \\
2.55 \\
\end{array}$ & $\begin{array}{l}3.62 \\
1.69 \\
\end{array}$ & $\begin{array}{l}1.46 \\
1.92 \\
\end{array}$ & $\begin{array}{l}1.80 \\
7.36 \\
\end{array}$ \\
\hline $\begin{array}{lll}\text { Satisfied } & \text { VS } & \text { Dissatisfied } \\
\text { Executives } & & \end{array}$ & $\begin{array}{l}\text { 't' } \\
\text { Value }\end{array}$ & $2.43^{*}$ & 1.59 & 1.53 & 1.21 & 1.21 \\
\hline
\end{tabular}


Calculated ' $t$ ' value (table-6) indicates that the satisfied and dissatisfied groups of supervisors are significantly different in their high task low relationship $(\mathrm{t}=2.22, \mathrm{p}<0.05)$, high task high relationship $(\mathrm{t}=10.23, \quad \mathrm{p}<0.01)$ and high relationship - low task $(\mathrm{t}=5.86, \mathrm{p}<0.01)$. however, low relationship low task. $(\mathrm{t}=1.58$, $\mathrm{P}>0.05$ ) leadership behavior shows the insignificant difference between the satisfied and dissatisfied group.

H6. Leadership styles and their effectiveness would be significantly different between a

Table 6 Leadership Styles and their effectiveness between a satisfied and dissatisfied group of supervisors with lower order needs in private organization.

\begin{tabular}{|l|l|l|l|l|l|l|}
\hline $\begin{array}{l}\text { Satisfied and dissatisfied group } \\
\text { of Supervisors with lower order } \\
\text { needs }\end{array}$ & $\begin{array}{l}\text { Mean } \\
\text { \& S.D }\end{array}$ & \multicolumn{3}{|l|}{ Leadership Styles } & $\begin{array}{l}\text { Leadership } \\
\text { effectiveness }\end{array}$ \\
\cline { 2 - 8 } & & HT LR & HT HR & HR-LT & LR-LT & Need \\
\hline Satisfied Supervisors (N=82) & Mean & 2.05 & 5.21 & 2.93 & 1.83 & 6.80 \\
& S.D. & 1.39 & 1.73 & 1.59 & 1.60 & 5.17 \\
\hline Dissatisfied Executives (N=80) & Mean & 2.54 & 2.55 & 4.57 & 2.24 & --0.2 \\
& s.d. & 1.70 & 1.49 & 2.02 & 1.91 & 5.80 \\
\hline $\begin{array}{l}\text { Satisfied VS Dissatisfied } \\
\text { Supervisors }\end{array}$ & 't' & $2.22^{*}$ & $10.23^{* *}$ & $5.86^{* *}$ & 1.58 & $8.14^{* *}$ \\
& Value & & & & & \\
\hline
\end{tabular}

${ }^{*} \mathrm{p}<0.05$

$* * \mathrm{p}<0.01$

Results clearly demonstrate that lower order needs satisfied respondents have adopted high relationship low task leadership behavior in the public organization and high task high relationship leadership behavior is preferred by the respondents of a private organization. Most of the respondents have preferred a similar pattern of leadership behavior in both public and private organization. Thus, respondents of the public organization seem to have higher participating leadership behavior than their counterparts and perceive that their followers have moderate to high maturity level. Maheshwari notes that 40 percent of the public sector managers indicate a high preference for participation, in comparison to $31.5 \%$ in the case of the private sector managers. Similarly, over 30 percent of managers in private organizations indicate a low preference for participation, as against about 19 percent in the case of managers in public organizations. Further is clearly noted that the managers in the public organizations have indicated a higher preference for participation than the managers in the private organization. High relationship low satisfied and dissatisfied group of supervisors with lower needs in private organizations.

Table 6 also shows the results on leadership effectiveness of the satisfied and dissatisfied (satisfaction with lower order need) group of supervisors in private organization and illustrates the leadership behavior of the satisfied group $(M=6.80$, S.D. $=5.17)$ is more effective rather than dissatisfied group $(\mathrm{M}=-0.2$, S.D. = 5.80). ' $T$ ' VALUE refers to the significant difference ( $\mathrm{t}=8.14$ ) between both groups and the statistically significant at 0.01 level.) task leadership behavior refers that high participative culture is in the public organization and thereby greater opportunities for participation for most of its members.

In the private organization, it is seen that lower order need satisfied respondents are neither extremely task-oriented nor highly relationship-oriented because they have preferred high task high relationship behavior \& precise that subordinates have low to maturity level. However, it is clear that the private organization puts more emphasize on consultation \& less emphasize on joint decision making or group participative leadership behavior.

In respect of dissatisfaction with the job Ronan (1970) narrates that dissatisfied employs are maladjusted. In the public organization (table 3 \& 4) it is noted that dissatisfied respondents (48 executives \& 52 supervisors) have adopted low relationship low task leadership behavior because of they precise that their subordinates have a high level. Dissatisfaction with the lower 
order needs indicates that respondents are self-deprived of their basic needs. Therefore they neither maintain their relationship with the subordinates nor are they capable of the decision making process. They do not their attention to the task to be performed. Due to these reasons, the executives have their subordinates for the self-decision at work. In contrary (private) organization executives \& supervisors have adopted distant leadership behavior because it is noted that where executives have preferred high task high relationship leadership behavior they only supervisors have preferred high relationship low task leadership behavior (table $5 \& 6$ ). It emphasizes that dissatisfied executives perceive their subordinates have moderate to high maturity level in the private organization. It is also noted (table 5) that both satisfied and dissatisfied executives in private organizations have adopted a similar pattern of leadership behavior (HT-HR) but mean value of leadership effectiveness reveals that high task high relationship leadership behavior of the satisfied group of executives is more effective in comparison to a dissatisfied group of executives. However, it is clear from table 5 that satisfaction and dissatisfaction do not play a significant role in the leadership behavior of the executive of the private organization. Both satisfied and dissatisfied executives have preferred high task high relationship leadership behavior. On the other had dissatisfied supervisors have preferred high relationship low task leadership behavior, but the mean value of leadership behavior is ineffective. It means preferred leadership behavior is not adopted by the respondents according to the situation.

Leadership effectiveness score indicates that satisfied respondents (with lower order needs) are effective in both organizations rather than dissatisfied respondents. It means satisfied respondents have adopted leadership behavior according to the situation and maturity level of the subordinates in comparison to dissatisfied respondents. Lawler and Porter (1967) reported that those who are satisfied with their work experience are more productive than those who are dissatisfied; however, it is clear that lower order needs satisfaction and dissatisfaction play a significant role in the behavior of the leaders except in the executives of the private organization.

\section{CONCLUSION}

The study was designed to investigate the need satisfaction, leadership styles, leadership effectiveness and the influence of need satisfaction and dissatisfaction of the executives and supervisors on leadership styles and leadership effectiveness. It was also intended to measure the relationship between lower and higher order need satisfaction with leadership style, i.e., HR-LR, HT-HR, HR-LT, and LR-LT in public and private organizations. ONGC, Surat was selected as a public organization and Essar Oil, Surat was selected as a private organization. A sample of 980 (public 430 and private 550) executives and the supervisor was given the porter need satisfaction questionnaire to measure the need fulfillment/dissatisfaction.

Leadership styles and leadership effectiveness were studied with the help of a LEAD questionnaire. The LEAD questionnaire is expounded by Hersey and Blanchard. The conclusion of the study are :

(1) The executives of the public and private organizations are not significantly different in case of the lower order needs and the result on higher order needs manifests that executives of the organizations are significantly different from each other.

(2) The supervisors of the public and privet organization are significantly different from each other. In need Hierarchy Level, i.e., lower and higher order needs.

(3) The respondents (executives and supervisors) of the public organization have preferred high relationship- low task leadership behavior as their dominant behavior. On the other hand, the respondents (executives and supervisors) of privet organization have preferred high task-high relationship behavior as their dominant behavior. The effectiveness variables imply that executives of public organist ions are more effective in comparison to executives of privet organizations, while supervisors of both organizations are equally effective. Because it is noted that the supervisor of both organizations is not significantly different from each other.

(4) Need Hierarchal level, i.e., lower and higher order need satisfaction/dissatisfaction influence on the leadership behavior of the leader except 
for the executives of the privet organization, and satisfied respondents (executives and supervisor) are effective in comparison to dissatisfied respondents (executives and supervisor).

(5) Lower order needs satisfaction does not influence on the leadership behavior of the managerial hierarchy (executives and supervisors) in both public and private organist ions. While higher order needs influence on the leadership behavior of the private organization supervisors rather than an executive of the private organization.

(6) Higher order needs the satisfaction of the executives is positively correlated with high task-high relationship leadership behavior, and the higher need satisfaction of the supervisors is negatively related with the task- low relationship leadership behavior in the public organization. On the other hand, the higher order need the satisfaction of the executives is positively correlated with the high relationship- low task leadership behavior and the lower order need the satisfaction of the supervisors is positively correlated with the high task-low relationship leadership behavior in privet organization.

This type of analysis of leader's (executives and supervisors) needs may be important for placing and promoting them. The need factor influences the productivity of any organist ion because it is supposed that the success of an organization depends upon the need and activities of the employees.

This study is very important not only from the academic angle but also in practice terms and would be helpful to identify the difference between the two distinct managerial levels in an organization and the distinction between the two organizations.

\section{SUGGESTIONS FOR FUTURE RESEARCH}

(1) In Future, an investigation can adopt the evaluated instrument of Hersay and Blanchard (1990), i.e., LEAD-other to measure the relationship style and leadership effectiveness. LEAD-other is written as to ask the subordinates to rate the boss, i.e., the leader would Zigarmi, Edeburn, and Blanchard (1990) noted that during the redesign of this instrument (LEAD- self and
LEAD-others), the authors attempted to construct items which depicted typical business situations and described combinations of commitment and competence in the development of the followers.

(2) With the subject of need/motives, other variables can be included, i.e., organizational effectiveness, stress, absenteeism, and other related variables.

(3) This study consists of only one public and one private organization. The sample can be taken from the conglomerates of the public and private organization from a different part of the country.

(4) The sample can be selected from top Managerial level of the executives and foreman.

(5) This study is conducted only on industrial employees. The employees of another department like; educational department and the medical department can also be studied.

\section{REFERENCES}

[1] Alpana Priyabhashini, Venkat R. Krishnan (2005), "Transformational leadership and follower"s career advancement: the role of pygmalion effect" Indian journal of industrial relations, vol.40, no.4, p.p 482-499.

[2] Argyrin, C: integrating the individual and the Organisation, Newyork Wiley 1964.

[3] Berelson, B. and Steiner, G: Human Behaviour, Newyork Harcourt, Brace and World 1964.

[4] David. M Harold, Donald Fedor (2008), "the effects of transformational and change leadership on employee ee s commitment to a change” Journal of applied psychology, vol 93, no. 2 p. 346-357.

[5] Desai, K.G.: A study of workers expectations from superiors and management, Indian Journal of social work, 30(2), 1969.

[6] Dunteman, E.A. and Bass, B.M. Supervisory and engineering success associated with self interaction and task orientation scores, personnel psychology, 16, 13-21,1963.

[7] Ganesan V. and Rajendran, K. Personality orientation and need satisfaction, Journal of Psychological Research 26, 17-22,1982. 
[8] Haire, M: Ghiselli, E. and Porter, L: Managerial Thinking: An international study, New York : Wiley, 1966.

[9] Hill, W.A. :Leadership style : Rigid or Flexible ? Organizational Behaviour and Human Performance, 9, 35-47, 1973.

[10]Northouse (2001) : “ Leadership ; theory and practice" thousand oaks, sage publications.

[11]Omar bin sayeed, Meera Shankar (2009), "Emotionally intelligent leaders and Transformational leadership styles” Indian journal of industrial relations, vol. 44 no. 4 p.593-610.
[12]Rosen, H. and Weaver, L.G. Motivation in management: A study of four managerial levels, Journal of Applied Psychology, 44, 386-392 1960.

[13]Vimal Babu (2011), “Divergent leadership styles practiced by Global managers in India” Indian journal of industrial relations, vol. 46, no. 3, p.p 478-490.

[14]Zenisek, T.: Corporate Social responsibility : A conceptual based on organization literature, Academy of Management Review: 4, 359-368.1979. 